\title{
Sustainability of Solid Waste Management System in Urban Areas of Pakistan: Stakeholders Perspective
}

\author{
Shoaib Muhammad*, M Sagheer Aslam**, Salman Saeed ${ }^{* * *}$ \\ *MSc Scholar (Urban Infrastructure Engineering), National Institute of Urban Infrastructure Planning, UET \\ Peshawar, KPK. \\ **Professor (Asst.), National Institute of Urban Infrastructure Planning, UET Peshawar, KPK \\ *** Professor (Asst.), National Institute of Urban Infrastructure Planning, UET Peshawar, KPK
}

\begin{abstract}
Sustainability of solid waste management system in Pakistan like other developing countries is a growing challenge. Stakeholders are vital for the successful running of solid waste management system and timely inclusion of stakeholders' perspective can contribute to attain sustainability of solid waste management system. Therefore, stakeholders' subjectivities and perspectives towards the sustainability of solid waste management system were studied in this research program. . Five components of the sustainable solid waste management system, that is, Technical, Environmental, Economic, Social and Institutional, were considered based on literature review. Nature of these components being part of an integrated system makes the system multicriteria. Relative importance of these components leading to define priorities for planning and execution of such system is the need for planning, development, and running of such systems. To acquire these priorities based on stakeholders input the stakeholders were classified into two major categories i.e. Technical and Social. A survey was undertaken in which the afore-mentioned stakeholders were asked to provide their input in the form of a pair wise comparison among the various components of the sustainable solid waste management system (SSWM). Analytical Hierarchy Process, a Multi Criteria Decision Analysis (MCDA) tool was used to quantify the relative importance of various components of SSWM. Environmental component of the sustainability came out to be the top priority of the stakeholders as it was given the highest weight by the stakeholders.
\end{abstract}

Keywords: Sustainability, Stakeholders, Stakeholder's perspective, AHP, Multi Criteria Decision Analysis

\section{INTRODUCTION}

Solid waste management system (SWMS) includes Solid Waste generation, collection, transport, processing, and disposal in a proper scientific sanitary manner. Accordingly, the system is linked with technical, environmental, social, economic, and institutional mechanisms. These components are fundamental for a sustainable SWMS. Effective running of a SWMS is directly associated with function of all stakeholders involved. Stakeholders are therefore defined as those groups or individuals who may affect, or be affected by a system, and/or those on whom the system is dependent for its survival [1]. On the basis of this definition, users, policy makers, operators and managers, and other groups that are related in any way can be identified as major stakeholders of a SWMS. For a successful running of the aforementioned system, it is of primary importance that priorities and subjectivities of stakeholders should be properly observed. Stakeholders have agreements and biases, which can affect the sustainability of a system, and better understanding of such biases and agreements is required for sustainable development [2].
As stakeholders' perspective for an entire SSWMS has not been studied in the context of sustainability components, many shortcomings and hindrances have been observed as briefly shown in the literature review. This research targeted at providing a major input to achieve sustainability of SWMS, which will help decreasing the problems faced by the system. The methodology consists of collecting data for deducing conclusion of Stakeholders' priorities by the use of Multi Criteria Analysis (MCA) using Analytic Hierarchy Process (AHP). It is expected that findings of this study will help entire setup of SWMS by better planning and execution.

\section{LITERATURE REVIEW}

The concept of sustainability was given importance after the Brundtland Report "Our Common Future" of the World Commission on Environment and Development [3]. The 2005 World Summit on Social Development defined sustainability in terms of environment, economic and social aspects [4].The United Nation Division for Sustainable Development added institutional factors to define sustainability. James Madison University defined sustainable engineering design by 
considering technical, economic, environmental and social factors [5]. These documents in connection with other literature provide a base for five major components of a sustainable system

Nature of a sustainable system, based on five major components of different nature, makes it multi-criteria. A number of approaches and method are available for multi-criteria analysis [6]. Huang et al. reviewed multiple papers to assess various Multi Criteria Decision Analysis methods and the results of review showed that AHP was used more frequently in projects similar to this research project [7]. AHP is capable of adjusting mixed data thus making it suitable for interdisciplinary research [8]. Deloitte applied AHP for suitable landfill site selection [9]. Elahi and Samadyar used AHP for landfill site selection with criteria including distance from residential buildings, distance from roads, distance from wells, geology, land-use, and distance from sensitive ecosystems [10]. R.L. Batagarawa and Romali et al. applied AHP for the selection of best waste treatment technology and Solid waste management optimization [11-12].

\section{DATA COLLECTION}

Respondents from group of technical and social stakeholders of SWMS were contacted randomly via emails, social media and by meeting in person. Respondents were also given the option of filling questionnaire online and for that purpose a web based online version of the questionnaire was prepared. Respondents were asked to make pair wise comparisons between the five components. 200 respondents were contacted via afore-mentioned means of communication. 77 respondents from technical group of stakeholders responded to the questionnaire and 43 respondents from the social group of stakeholders responded to the questionnaire. Consequently, the response rate was $60 \%$. Technical group of stakeholders were comparatively more responsive to the questionnaire.

\section{DATA ANALYSIS AND RESULTS}

After obtaining the pair-wise comparisons, AHP was applied to translate the subjectivities of stakeholders into numbers (Percentage). The distribution of respondents based on group of stakeholders is shown below in fig.1.

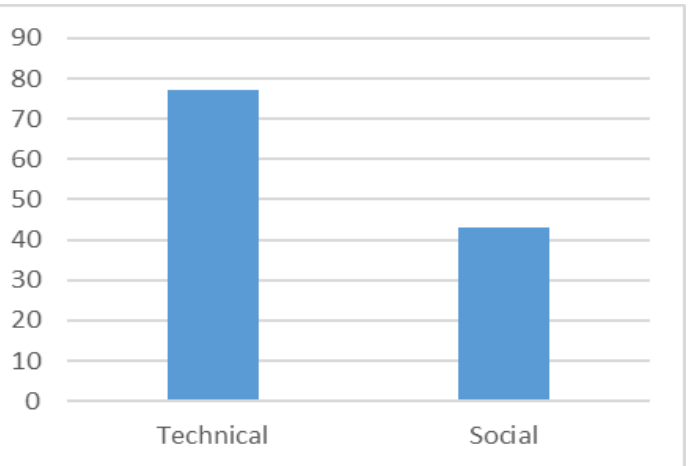

Figure 1: Distribution of respondents based on group of stakeholders.

Results obtained for the technical group of stakeholders are given below. 77 stakeholders from the technical group responded to the questionnaire. The single input matrix after combining all the responses via geometric mean is given below.

Table 1: Input matrix for technical Stakeholders

\begin{tabular}{|l|l|l|l|l|l|}
\hline & $\mathrm{T}$ & $\mathrm{N}$ & $\mathrm{E}$ & $\mathrm{S}$ & $\mathrm{I}$ \\
\hline $\mathrm{T}$ & 1 & 1.38 & 1.31 & 0.90 & 1.17 \\
\hline $\mathrm{N}$ & 0.73 & 1 & 1.66 & 1.33 & 1.29 \\
\hline $\mathrm{E}$ & 0.76 & 0.60 & 1 & 0.97 & 1.04 \\
\hline $\mathrm{S}$ & 1.11 & 0.75 & 1.03 & 1 & 1.33 \\
\hline $\mathrm{I}$ & 0.86 & 0.77 & 0.96 & 0.75 & 1 \\
\hline
\end{tabular}

Note: $(\mathrm{T}=$ Technical, $\mathrm{N}=$ Environmental, $\mathrm{E}=$ Economic, $\mathrm{S}=$ Social, $\mathrm{I}=$ Institutional)

Weights allocated by the technical group of stakeholders to the various components of sustainability are shown below.

Table 2: Normalized comparison matrix

\begin{tabular}{|l|l|l|l|l|l|l|l|}
\hline & $\mathrm{T}$ & $\mathrm{N}$ & $\mathrm{E}$ & $\mathrm{S}$ & $\mathrm{I}$ & $\mathrm{W}$ & $\mathrm{W} \%$ \\
\hline $\mathrm{T}$ & 0.22 & 0.30 & 0.21 & 0.18 & 0.20 & 0.22 & 22.63 \\
\hline $\mathrm{N}$ & 0.16 & 0.22 & 0.27 & 0.26 & 0.22 & 0.23 & 23.06 \\
\hline $\mathrm{E}$ & 0.17 & 0.13 & 0.16 & 0.19 & 0.17 & 0.16 & 16.92 \\
\hline $\mathrm{S}$ & 0.24 & 0.16 & 0.17 & 0.20 & 0.22 & 0.20 & 20.39 \\
\hline $\mathrm{I}$ & 0.19 & 0.17 & 0.16 & 0.15 & 0.17 & 0.16 & 16.96 \\
\hline
\end{tabular}

Note: $\mathrm{W}=$ Weights

Consistency ratio for the technical stakeholders, which is a reflection of the consistency of the responses, came out to be $1.27 \%$. Results obtained for the social stakeholders are mentioned below. Single representative input matrix obtained after combining 43 individual responses via geometric mean is mentioned below.

Table 3: Input matrix for social stakeholders

\begin{tabular}{|l|l|l|l|l|l|}
\hline & $\mathrm{T}$ & $\mathrm{N}$ & $\mathrm{E}$ & $\mathrm{S}$ & $\mathrm{I}$ \\
\hline $\mathrm{T}$ & 1 & 1.07 & 1.19 & 0.69 & 0.86 \\
\hline $\mathrm{N}$ & 0.93 & 1 & 2.03 & 0.97 & 1.31 \\
\hline $\mathrm{E}$ & 0.84 & 0.49 & 1 & 0.87 & 1.14 \\
\hline $\mathrm{S}$ & 1.44 & 1.03 & 1.15 & 1 & 2.07 \\
\hline $\mathrm{I}$ & 1.16 & 0.76 & 0.88 & 0.48 & 1 \\
\hline
\end{tabular}


Weights allocated by the social group of stakeholders to the various components of sustainability are shown below.

Table 4: Normalized comparison matrix

\begin{tabular}{|l|l|l|l|l|l|l|l|}
\hline & $\mathrm{T}$ & $\mathrm{N}$ & $\mathrm{E}$ & $\mathrm{S}$ & $\mathrm{I}$ & $\mathrm{W}$ & $\mathrm{W} \%$ \\
\hline $\mathrm{T}$ & 0.19 & 0.25 & 0.19 & 0.17 & 0.13 & 0.19 & 18.58 \\
\hline $\mathrm{N}$ & 0.17 & 0.23 & 0.32 & 0.24 & 0.21 & 0.24 & 23.52 \\
\hline $\mathrm{E}$ & 0.16 & 0.11 & 0.16 & 0.22 & 0.18 & 0.16 & 16.49 \\
\hline $\mathrm{S}$ & 0.27 & 0.24 & 0.18 & 0.25 & 0.32 & 0.25 & 25.23 \\
\hline $\mathrm{I}$ & 0.22 & 0.17 & 0.14 & 0.12 & 0.16 & 0.16 & 16.17 \\
\hline
\end{tabular}

Consistency ratio for social stakeholders came out to be $2.22 \%$.

\section{CONCLUSIONS}

Technical stakeholders gave highest preference to environmental component followed by technical component. Social component of the sustainability came in third place on the priority list of technical stakeholders.

Social stakeholders gave highest preference to social component, followed by environmental component of the sustainability. Technical component of the sustainability stood out third on the priority list of social stakeholders.

\section{RECOMMENDATIONS}

Similar work should be done by involving environmental, economic and institutional stakeholders. Stakeholders' perspective for the complete hierarchy of system, which should include the factors/sub factors within each component, should be determined.

\section{ACKNOWLEDGEMENTS}

This work is a part of MSc research of the first author. Support and guidance of the faculty and support staff in NIUIP, UET Peshawar is thankfully acknowledged. Volunteer participation of stake holders is also sincerely acknowledged, without their contribution, this research would not have been possible.

\section{REFERENCES}

[1]. R.E. Freeman and D.L. Reed, "Stockholders and Stakeholders: A New Perspective on Corporate Governance." California Management Review 25(3): 88106, 1983

[2]. M.S. Aslam, et al, "Sustainable community-based drinking water systems in developing countries: stakeholder perspectives," J. Water Supply Res. Technol., vol. 5, no. 65, pp. 407-416, 2016.

[3]. WCED (World Commission on Environment and Development), "Our common future". Oxford: Oxford University Press, 1987.

[4]. Johannesburg, South Africa, "Report of the World Summit on Sustainable Development", UN, A/CONF.199/20, 2002

[5]. E. Pappas, "A New Systems Approach to Sustainability: University Responsibility for Teaching Sustainability in Contexts", Journal of Sustainability Education Vol. 3, ISSN: 2151-7452, March 2012

[6]. M. S. Aslam, "sustainability of communitybased drinking water systems in developing countries", Ph.D. thesis, Department of Civil Engineering and Applied Mechanics McGill University, Montreal, Quebec, Canada, September 2013.

[7]. I.B. Huang, et al., "Multi-Criteria Decision Analysis in Environmental Sciences: Ten Years of Applications and Trends." Science of The Total Environment 409(19): 35783594, 2011.

[8]. M. Garfi, et al., "Multi- Criteria Analysis for Improving Strategic Environmental Assessment of Water Programmes. A Case Study in Semi-Arid Region of Brazil." Journal of Environmental Management 92(3): 665- 675, 2011.

[9]. Deloitte, "Minding your Stakeholders' business: The key to sustainability", Retrieved from http://www.ebook4shared.com/docfile/minding-your-stakeholders-businessthe-key-to-sustainability, 2011.

[10]. A. Elahi, and H. Samadyar, "Municipal Solid Waste Landfill Site Selection Using Analytic Hierarchy Process Method for Tafresh Town", Middle-East Journal of Scientific Research, 22(9), 1294-1307. https://doi.org/10.5829/idosi.mejsr.2014.22. 09.21545, 2014.

[11]. R. L. Batagarawa, "Sustainability appraisal of waste management in Nigeria: Development and evaluation of an index based tool", 151, july 2011.

[12]. N. Romali, et al., "Solid waste management: Development of AHP model for application of landfill sites selection in Kuantan, Pahang, Malaysia", Proceedings of the International Symposium on the Analytic Hierarchy Process, 1-9. Retrieved from

http://scholar.google.com.my/citations?vie w_op $=$ view_citation\&hl=en\&user $=q v w 3 u 2$ QAAA, (2013). 